\title{
Sialolith and adenoid cystic carcinoma in the submandibular gland. A rare case
}

\author{
Kanwar Deep Singh Nanda ${ }^{1}$, Anurag Mehta ${ }^{2}$ \\ ${ }^{1}$ Senior lecturer. Department of Oral and Maxillofacial Pathology. SGT Dental College and Hospital, Gurgaon, Haryana, India. \\ ${ }^{2}$ Head of Laboratory Services. Department of Pathology. Rajiv Gandhi Cancer Institute \& Research Centre, Sector-V, Rohini, \\ Delhi, India.
}

Correspondence:

18/15 West Patel Nagar

New Delhi

110008, India

E-mail address: kdsnanda@gmail.com

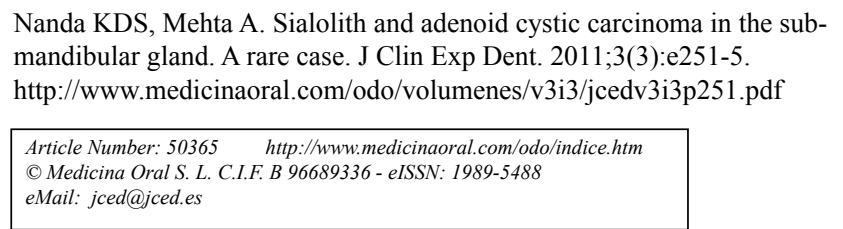

\begin{abstract}
Salivary calculi occur most frequently in the submandibular gland of the human beings. It is because of the specific anatomy of both the glands and its duct. Presentation typically consists of a painful swelling of the gland at meal times, when the effect of obstruction is most acute. The clinical signs, in most of times, can lead us to the diagnosis easily. The coexistence of sialolith and malignant tumors are very rare. This case report is about a male patient of 45 year with a swelling in the submandibular region for the last eighteen months with an intermittent episode of moderate to severe pain which increased during a mealtime and diagnosed as sialolith on radiograph, but on biopsy proved to be adenoid cystic carcinoma along with sialolith. This case report describes the coexistence of sialolithiasis and adenoid cystic carcinoma in the submandibular gland with advantages and limitations of various imaging studies to be used by health care professionals prior to reaching definitive conclusion.
\end{abstract}

Key words: Sialolithiasis, Adenoid cystic carcinoma, Submandibular gland, imaging techniques. 


\section{Introduction}

Sialolithiasis is a common cause of salivary gland disease characterized by the occurrence of sialolith in the different parts of salivary glands with a prevalence rate of approximately $1.2 \%$ (1). Sialoliths are calcified structures that develop within the salivary ductal system. Sialoliths are hard formations with round or oval shape and a variety of sizes (2). Some $80-90 \%$ of calculi are found in the submandibular gland, $5-10 \%$ in the parotid and approximately $0-5 \%$ in the sublingual and other minor salivary glands (3). Stones preferentially affect men, with a peak incidence in the fourth and fifth decades (2). Presenting symptoms as a result of ductal obstruction includes episodic swelling and postprandial pain (4). Adenoid cystic carcinoma (ACC) is one of the most common malignant tumors of epithelial origin in the submandibular gland and constitutes 30 to $40 \%$ of malignant tumors of minor salivary glands. It is characterized by a high tendency of recurrence, early nerve infiltrations and hematogenous metastasis (5). The coexistence of sialolith and malignancies has been reported for parotid but not for submandibular gland (6). The aim of this case is to report the coexistence of sialolithiasis and adenoid cystic carcinoma of the submandibular gland. However, the use of conventional imaging techniques can be misleading as seen in the present case. Advanced imaging studies are useful to health care professionals where they feel high suspicion index before operating in patient with sialolithiasis.

\section{Case Report}

A 45 year old male noticed a swelling in the submandibular region for the last 18 months. He reported to department of Oral Pathology and Microbiology one year

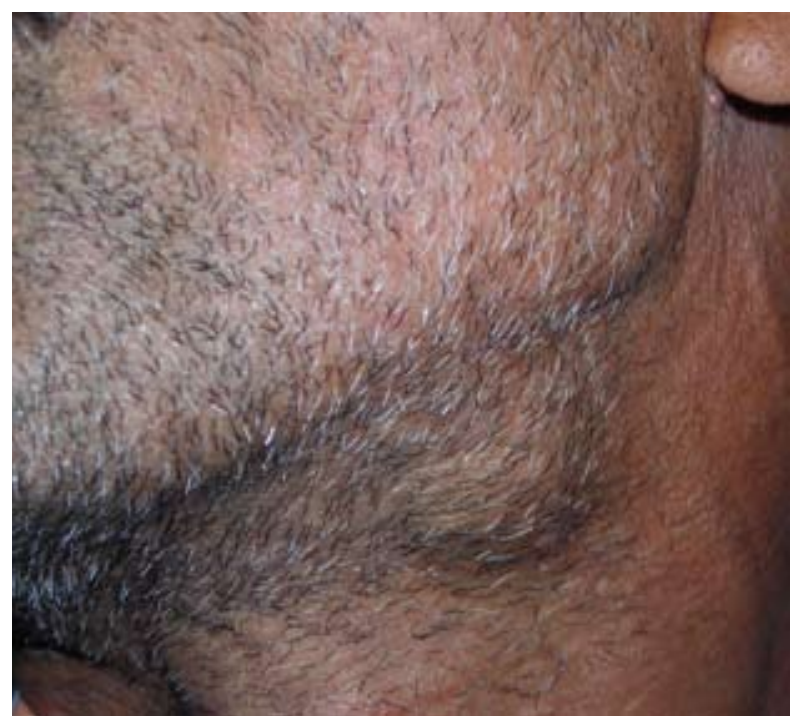

Fig. 1. A well defined hard and tender swelling in the left submandibular region

back with the same problem and was diagnosed sialolith in relation to left submandibular gland but did not report for further treatment. Presently patient has moderate to severe pain which increase during mealtimes and swelling in the same region with an occasional feeling of numbness. He had undergone extraction of lower left second molar two years back. A hard and tender swelling in the left submandibular region of approximately $1 \times 1.5 \mathrm{~cm}$ was palpated (Figure 1). Intra oral examination revealed scanty salivary flow from the duct of the left submandibular gland. The medical, social and family histories were unremarkable. A complete blood investigation revealed no abnormal finding. The orthopantomogram revealed a well defined radiopaque mass on the left lower border of the mandible (Figure 2). The

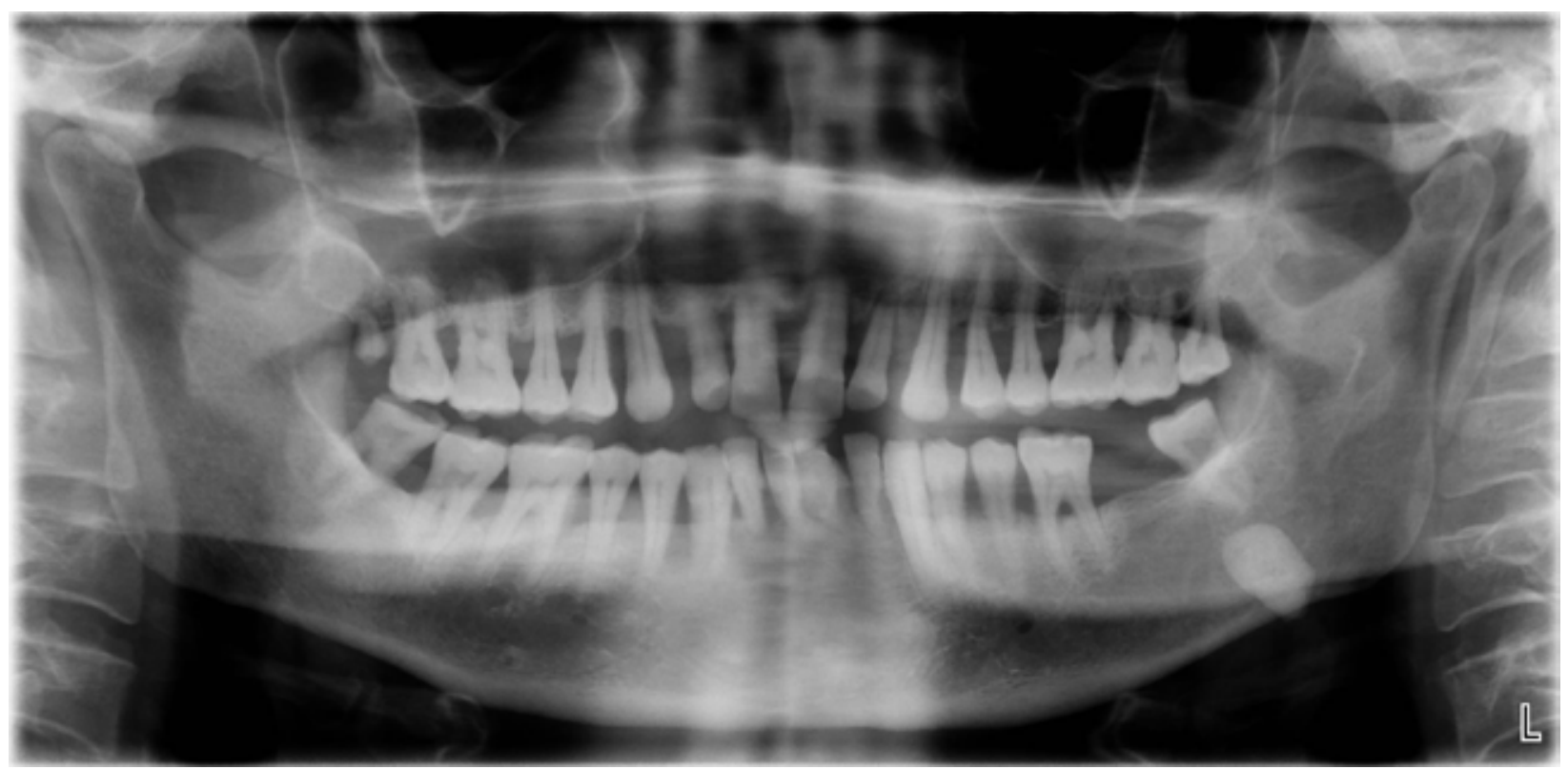

Fig. 2. OPG showing a well defined radiopaque mass on the left lower border of the mandible. 


\begin{tabular}{|c|c|c|c|c|}
\hline $\begin{array}{c}\text { IMAGING } \\
\text { TECHNIQUES }\end{array}$ & PRINCIPLE & ADVANTAGES & DISADVANTAGES & $\begin{array}{l}\text { USES (in relation to } \\
\text { salivary glands) }\end{array}$ \\
\hline $\begin{array}{l}\text { Conventional } \\
\text { radiograph }\end{array}$ & $\begin{array}{l}\text { Beam of photons } \\
\text { exit an object and } \\
\text { exposes an x ray } \\
\text { film thus changes the } \\
\text { photosensitive silver } \\
\text { halide crystals. The- } \\
\text { se chemically altered } \\
\text { silver bromide crys- } \\
\text { tals constitute the la- } \\
\text { tent (invisible) ima- } \\
\text { ge on the film. The } \\
\text { developing process } \\
\text { converts the latent } \\
\text { image into visible ra- } \\
\text { diographic image. }\end{array}$ & $\begin{array}{l}\text { Easy to perform as } \\
\text { compared to con- } \\
\text { ventional sialogra- } \\
\text { phy. } \\
\text { Develops in short } \\
\text { time } \\
\text { Less patient com- } \\
\text { pliance } \\
\text { Records can be } \\
\text { maintained for long } \\
\text { time. }\end{array}$ & $\begin{array}{l}10 \%-20 \% \text { of sialoliths } \\
\text { in the submandibular } \\
\text { gland or duct are not ra- } \\
\text { diopaque and therefore, } \\
\text { are not visible on radio- } \\
\text { graphs. Calcified phle- } \\
\text { bolithiasis, hemangio- } \\
\text { mas and lymph nodes } \\
\text { may mimic sialoliths on } \\
\text { radiographs }\end{array}$ & $\begin{array}{l}\text { Sialoliths present in } \\
\text { anterior two third of } \\
\text { submandibular duct } \\
\text { can be imaged fre- } \\
\text { quently by both IOPA } \\
\text { (Intraoral periapical } \\
\text { radiograph) and ex- } \\
\text { tra-oral radiography. }\end{array}$ \\
\hline $\begin{array}{l}\text { Conventional } \\
\text { Sialography }\end{array}$ & $\begin{array}{l}\text { Radiograph is taken } \\
\text { after insertion of } \\
\text { contrast media in the } \\
\text { salivary gland. }\end{array}$ & $\begin{array}{l}\text { Detection of sialo- } \\
\text { liths. } \\
\text { Evaluation of diver- } \\
\text { ticula, strictures and } \\
\text { fistula. }\end{array}$ & $\begin{array}{l}\text { Invasive method. Com- } \\
\text { plications such as blee- } \\
\text { ding, traumatic perfo- } \\
\text { ration or rupture of the } \\
\text { submandibular duct. } \\
\text { Contraindicated in pa- } \\
\text { tients with an active } \\
\text { infection. Allergic reac- } \\
\text { tion to components of } \\
\text { radio-opaque material. }\end{array}$ & $\begin{array}{l}\text { Detection of sialoli- } \\
\text { ths. } \\
\text { Evaluation of diver- } \\
\text { ticula, strictures and } \\
\text { fistula. Help in } \\
\text { the differentiation of } \\
\text { Sjogren's syndrome, } \\
\text { sailosis and chronic } \\
\text { sialadenitis. }\end{array}$ \\
\hline Ultrasound & $\begin{array}{l}\text { When sound waves } \\
\text { above } 20,000 \mathrm{~Hz} \\
\text { meet the object, the } \\
\text { density changes and } \\
\text { are partly reflected } \\
\text { and received back } \\
\text { by transducer and an } \\
\text { image is made. }\end{array}$ & $\begin{array}{l}\text { It is noninvasive and } \\
\text { can be performed in } \\
\text { patients with acute } \\
\text { sialadenitis. Mo- } \\
\text { reover, there is no } \\
\text { radiation exposure. }\end{array}$ & $\begin{array}{l}\text { Small ( } 3 \mathrm{~mm} \text { diameter) } \\
\text { sialoliths may not be de- } \\
\text { tected with ultrasound } \\
\text { because they may not } \\
\text { produce a dorsal acous- } \\
\text { tic shadow, depending } \\
\text { on their chemical com- } \\
\text { position. }\end{array}$ & $\begin{array}{l}\text { Helpful in determi- } \\
\text { ning salivary gland } \\
\text { tumors, solid and } \\
\text { cystic masses, auto- } \\
\text { immune sialadenitis } \\
\text { and sialoliths. }\end{array}$ \\
\hline CT Scan & $\begin{array}{l}\text { Collimated fan sha- } \\
\text { ped X-ray beam, } \\
\text { directed towards } \\
\text { object to a series of } \\
\text { ionization chambers. } \\
\text { Number of photons } \\
\text { exiting from patient } \\
\text { is measured for cons- } \\
\text { truction of image. }\end{array}$ & $\begin{array}{l}\text { Different planes } \\
\text { can be visualized. } \\
\text { Greater sensitivi- } \\
\text { ty. Changes } \\
\text { less than } 1 \% \text { can be } \\
\text { visualized. }\end{array}$ & $\begin{array}{l}\text { Radiation dose higher } \\
\text { than radiography proce- } \\
\text { dures. } \\
\text { Expensive machine. } \\
\text { Great difficulty in ima- } \\
\text { ging metallic objects. }\end{array}$ & $\begin{array}{l}\text { Useful in evaluating } \\
\text { salivary glands and } \\
\text { adjacent parts. As- } \\
\text { sessing acute inflam- } \\
\text { matory process and } \\
\text { sialoliths. }\end{array}$ \\
\hline
\end{tabular}




\begin{tabular}{|c|c|c|c|c|}
\hline MRI & $\begin{array}{l}\text { R a di o freque n cy } \\
\text { waves causes the nu- } \\
\text { clei to tilt away from } \\
\text { magnetic field, as the } \\
\text { nuclei return to their } \\
\text { alignment, gives off } \\
\text { minute radio signals } \\
\text { in 3D by which ima- } \\
\text { ge is constructed. }\end{array}$ & $\begin{array}{l}\text { It offers better reso- } \\
\text { lution than CT scan } \\
\text { Non- invasive. } \\
\text { No ionizing radia- } \\
\text { tion. Direct multi } \\
\text { planar imaging can } \\
\text { be done without re- } \\
\text { orienting patient. }\end{array}$ & $\begin{array}{l}\text { Long imaging time. } \\
\text { Contraindicated in pa- } \\
\text { tients with pacemaker } \\
\text { and cerebral implants. } \\
\text { Relatively expensive. } \\
\text { Can Induce claustro- } \\
\text { phobia in patients. } \\
\text { Minor physiological } \\
\text { changes in length of } \\
\text { cardiac cycle. }\end{array}$ & $\begin{array}{l}\text { Evaluating salivary } \\
\text { glands and adjacent } \\
\text { parts better than CT } \\
\text { Scan. Assess acute } \\
\text { inflammatory process } \\
\text { better. } \\
\text { Contrast material } \\
\text { helps in distinguis- } \\
\text { hing between solid } \\
\text { and cystic masses in } \\
\text { evaluation of peri- } \\
\text { neural spread of ma- } \\
\text { lignancy. }\end{array}$ \\
\hline Sialoendoscopy & $\begin{array}{l}\text { Small flexible tube } \\
\text { with a light and lens } \\
\text { on one end is used to } \\
\text { visualize the body } \\
\text { cavity. }\end{array}$ & $\begin{array}{l}\text { Minimally invasive } \\
\text { technique. } \\
\text { Remove sialolith } \\
\text { from deeper portion } \\
\text { of the ducts and wi- } \\
\text { thin the glands and } \\
\text { opening of strictu- } \\
\text { res, kinks and duct } \\
\text { strictures. } \\
\text { Identify radiolucent } \\
\text { stones, polyps, ste- } \\
\text { nosis, mucous plugs } \\
\text { and foreign bodies. } \\
\text { Surrounding tissues } \\
\text { are minimally da- } \\
\text { maged. }\end{array}$ & $\begin{array}{l}\text { Contraindicated in acu- } \\
\text { te inflammatory condi- } \\
\text { tions such as sialadeni- } \\
\text { tis and non functioning } \\
\text { gland. } \\
\text { Can not be used in in- } \\
\text { traparenchymal stones } \\
\text { and ductal lumen which } \\
\text { cannot be enlarged to } \\
1.3 \mathrm{~mm} \text {. }\end{array}$ & $\begin{array}{l}\text { Screening of ductal } \\
\text { system to rule out } \\
\text { any residual calculi } \\
\text { after surgical sialoli- } \\
\text { thotomy. } \\
\text { Remove calculus of } \\
\text { diameter less than } \\
7 \mathrm{~mm} \text { in Wharton's } \\
\text { duct and } 5 \mathrm{~mm} \text { in } \\
\text { Stensen's duct. } \\
\text { When calculus remo- } \\
\text { val by conventional } \\
\text { method is hazardo- } \\
\text { us to perform as in } \\
\text { posterior portion of } \\
\text { Wharton's duct with } \\
\text { its proximity to lin- } \\
\text { gual nerve. }\end{array}$ \\
\hline
\end{tabular}

CT- Computed tomography

MRI- Magnetic resonance imaging

Table 1. A comparison between various imaging techniques

patient underwent an ultrasound that revealed a stone at the terminal end of the submandibular gland and dilated duct. We could not do a CT and MRI as it was not possible in our setup and the patient could not afford it in other laboratories. The patient was scheduled for surgical removal of submandibular gland and stone along with modified radical neck dissection under general anesthesia. The gross examination of the excised tissue showed the gland which was strongly adhering to the neighboring tissues. The stone was hard and yellow in color. Histological analysis revealed islands of basaloid epithelial cells that contain multiple cylindric cyst like spaces resembling 'Swiss cheese'. These spaces contain mild basophilic mucoid material. In addition some areas exhibit hyalinized material surrounding these cribiform islands. The tumor cells were small cuboidal exhibiting deeply basophilic nuclei and little cytoplasm (Figure 3). A final diagnosis of adenoid cystic carcinoma was rendered following confirmation by histopathology.

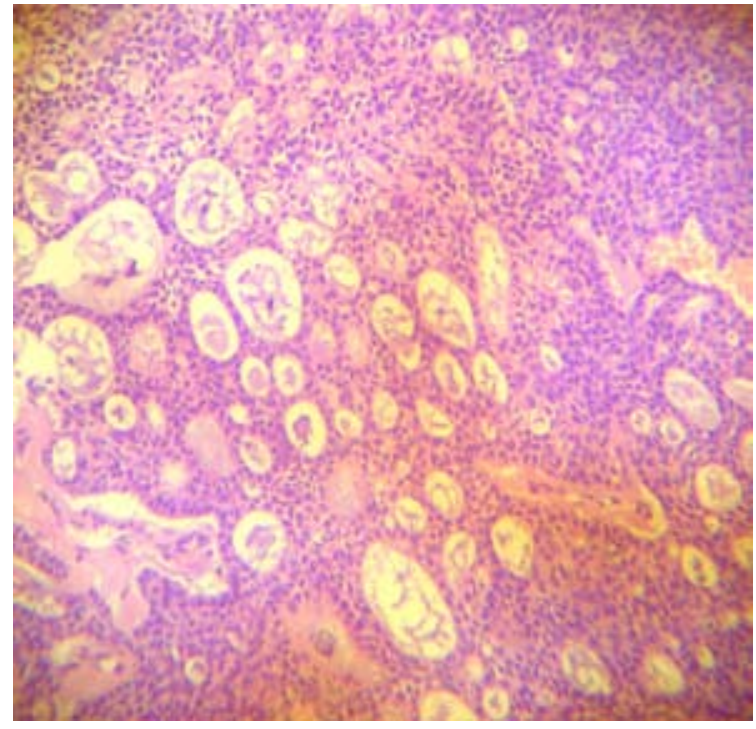

Fig. 3. Haematoxylin \& Eosin section showing islands of basaloid epithelial cells containing multiple cylindric cyst like spaces resembling 'Swiss cheese'suggestive of Adenoid cystic carcinoma 


\section{Discussion}

Sialolithiasis accounts for half of major salivary gland disease which can be asymptomatic for a long time. Sialoliths are usually composed of round organic cores which are intensely calcified and are surrounded by alternative layers of organic and inorganic substances (7). Ductal inflammation as well as increased viscosity and stasis of saliva have been suggested as predisposing factors. The increased viscosity and mineral content of the submandibular saliva and upward, curved path of the submandibular duct predispose to stone formation in this gland (8). It is important to differentiate sialolithiasis from tumor of the salivary gland. The coexistence of sialolith and malignancies like multiple myeloma and lymphoma has been reported for parotid but not for submandibular gland $(6,9)$.

Adenoid cystic carcinoma is a rare tumor and form about $1 \%$ of all malignant tumors of the oral and maxillofacial region (10). The female to male ratio is approximately $3: 2$. Adenoid cystic carcinoma can occur in any salivary gland, but approximately 50\% develop within the minor salivary glands with parotid the most common site of occurrence (11). In the submandibular gland, this tumor accounts for $12 \%$ to $17 \%$ of all tumors (12).

A possibility of tumor was ruled out for this patient because swelling, pain and paresthesia were not constant and a radiopaque nodule was detected in OPG. Moreover stones most commonly occur in the submandibular gland between 80 to $90 \%$ (3).

Conventional radiographic methods like orthopantomogram (OPG) are still widely used in detection of calcification which is sometimes misleading as seen in our case. Recent imaging techniques like Ultrasound (US), Computed Tomography (CT), Magnetic resonance imaging (MRI), Sialography, Digital sialography, Digital subtraction sialography, CT sialography and MR Sialography add substantial new information of glandular and ductal changes as compared to use conventional radiograph (13). Various imaging techniques are compared in Table1.

Overall, digital sialography continues to be the standard technique for imaging of the submandibular duct and the intraglandular ductal system (14). If acute sialadenitis is present or insertion of a cannula into the submandibular duct is not successful. In such cases, noninvasive MR sialography with adequate evoked salivation as a natural contrast material provides an excellent alternative (15), especially when performed with a combination of RARE (Rapid Acquisition with Relaxation-Enhancement) and 3D CISS (Constructive Interference in Steady-State) sequences. Furthermore, MR Sialography is superior to US with regard to the detection of sialoliths, as it allows delineation of small anatomic structures and is noninvasive also (14). To conclude, a full diagnostic work up with the help of various radiological and histopatholo- gical techniques is required before making a confirmed diagnosis.

\section{References}

1. Lustmann J, Regev E, Melamed Y. Sialolithiasis A survey on 245 patients and a review of the literature. Int J Oral Maxillofac Surg. 1990; 19: 135-8.

2. Tandler B. Electron microscopical observations on early sialoliths in a human submaxillary gland. Arch Oral Biol. 1965; 10:509-22.

3. Bonder L. Salivary gland calculi: diagnostic imaging and surgical management. Compendium. 1993; 14: 572, 574-6.

4. McGurk M, Escudier MP, Brown JE. Modern management of salivary calculi. Br J Surg. 2005; 92:107-12.

5. González Lagunas J, Rodado C, Raspall G, Bermejo B, Huguet P, Giralt J. Malignant tumors of the minor salivary glands. Retrospective study on 59 cases. Med Oral Patol Oral Cir Bucal. 2001; 6:142-7.

6. Haring JI. Diagnosing salivary stones. J Am Dent Assoc. 1991; 122 : 75-6.

7. Scott J. The prevalence of consolidated salivary deposits in the small ducts of human submandibular glands. J Oral Pathol. 1978; 7: 28-37.

8. Epker BN. Obstruction and inflammatory diseases of the major salivary glands. Oral Surg Oral Med Oral Pathol. 1972; 33: 2-27.

9. Batzakakis D, Apostolopoulos K, Bardanis I. A case report of coexistence of a sialolith and an adenoid cystic carcinoma in the submandibular gland. Med Oral Patol Oral Cir Bucal. 2006; 11:E286-8.

10. Kokemueller H, Eckardt A, Brachvogel P, Hausamen JE. Adenoid cystic carcinoma of head and neck- a 20 year experience. Int J Oral Maxillofac Surg. 2004; 33: 25-31.

11. Avery CM, Moody AB, Mckinna FE, Taylor J, Henk JM, Langdon JD. Combined treatment of adenoid cystic carcinoma of the salivary glands. Int J Oral Maxillofac Surg. 2000; 29: 277-9.

12. Jones AS, Hamilton JW, Rowley H, Husband D, Helliwell TR. Adenoid cystic carcinoma of the head and neck. Clin Otolaryngol Allied Sci. 1997; 22, 434-43.

13. Rinast E, Gmelin E, Hollands Thorn B. Digital subtraction sialography, conventional sialography, high-resolution ultrasonography and computed tomography in the diagnosis of salivary gland diseases. Eur J Radiol. 1989; 9:224-30.

14. Jäger L, Menauer F, Holzknecht N, Scholz V, Grevers G, Reiser M. Sialolithiasis: MR sialography of the submandibular duct- an alternative to conventional sialography and US? Radiology 2000; 216:665-71.

15. Yousem DM, Kraut MA, Chalian AA. Major salivary gland imaging. Radiology 2000; 216:19-29. 